\title{
PENGARUH PENUTUPAN MULSA ORGANIK TERHADAP PERKEMBANGAN GULMA HUTAN TANAMAN NYAWAI (Ficus variegata $\mathrm{BI}$ )
}

\section{The Influence of Organic Mulching on Weed Growth of Nyawai (Ficus variegata B1) Stand}

\author{
Acep Akbar \\ Balai Penelitian dan Pengembangan Lingkungan Hidup dan Kehutanan Banjarbaru \\ Jl. JL. Ahmad Yani, KM. 28, 7, Landasan Ulin, Banjarbaru 770721, Kota Banjar Baru, Indonesia \\ Kalimantan Selatan, Indonesia \\ Telp. 0511 - 4707872, Fax. 0511 - 4707872 \\ Email : acep_akbar@yahoo.com
}

Tanggal diterima :15 Mei 2015; Tanggal direvisi : 22 November 2016; Tanggal disetujui :

\begin{abstract}
Abundant weeds hamper tree growth and increase the risk offorest fire in the plantation forest. This study aimedr to determine the effect of organic mulching on the weed growth under nyawai stand. The experiment was designed using factorial in randomized complete block design. The results found the presence of 11 types of weeds, dominated by alang-alang (Imperata cylindrica L. Raeusch) and jepangan (Clibadium surinamense L.). Alang-alang organic mulch had the slowest decomposition process and alang-alang mulching for 3 months supressed weed growth. Organic mulching had no significanteffect to height and diameter growth of nyawai stand and to crown diameter nyawai. The highest additional nutrient phosphorus and potassium were generated from Piper aduncum mulching, and nitrogen from jepangan mulching.
\end{abstract}

Keyword: Nyawai, organic mulch, plantation, weeds

\begin{abstract}
ABSTRAK
Kehadiran gulma yang berlimpah menimbulkan gangguan pertumbuhan pada tanaman pokok dan meningkatkan risiko kebakaran di hutan tanaman. Penelitian ini bertujuan untuk mengetahui pengaruh mulsa organik terhadap perkembangan gulma tegakan nyawai. Penelitian menggunakan rancangan faktorial dalam rancangan acak kelompok. Hasil penelitian menunjukkan adanya 11 jenis gulma yang didominasi oleh rumput alang-alang (Imperata cylindrica L. Raeusch) dan jepangan (Clibadium surinamense L.). Mulsa organik alang-alang memiliki laju dekomposisi paling lambat dan pemberian mulsa organik alang-alang selama 3 bulan mampu menekan kehadiran gulma. Penutupan mulsa organik tidak berpengaruh secara signifikan terhadap pertumbuhan tinggi dan diameter nyawai maupun diameter tajuk nyawai. Mulsa Piper aduncum L. menghasilkan tambahan unsur hara phospor dan kalium tertinggi adapun mulsa rumput jepangan meningkatkan unsur hara nitrogen yang tertinggi.
\end{abstract}

Kata kunci: Gulma, hutan tanaman, mulsa organik, nyawai

\section{PENDAHULUAN}

Pembangunan hutan tanaman mutlak diperlukan guna memenuhi kebutuhan manusia terhadap kayu baik untuk keperluan bangunan, kerajinan dan energi maupun untuk kepentingan mitigasi perubahan iklim. Keberadaan dan keberlanjutan hutan tanaman diperlukan setelah hutan alam tidak lagi berfungsi optimal sebagai penghasil kayu (Effendi, 2010). Namun pembangunan Hutan Tanaman Industri (HTI) memerlukan investasi besar dengan jangka pengembalian yang lama dan berisiko tinggi. Oleh karena itu, produktivitas tegakan yang tinggi merupakan sasaran utama dalam pembangunan HTI. Untuk mencapai sasaran tersebut diperlukan teknik silvikultur yang tepat dengan menerapkan teknik pengendalian hama, penyakit dan gulma secara intensif.

Kehadiran gulma yang berlimpah selain dapat menyebabkan gangguan pertumbuhan, juga dapat meningkatkan risiko kebakaran hutan, terutama apabila gulma tersebut didominasi rumput alang-alang (Imperata cylindrica L. Raeusch) (Nagochi et al., 2009). Pengendalian gulma ditujukan untuk menciptakan kondisi agar gulma tumbuh tidak terlalu rapat sehingga dapat menghalangi masuknya penetrasi cahaya ke 
lantai hutan. Umumnya semua jenis gulma sensitif terhadap cahaya. Jika cahaya matahari berkurang atau tidak ada sama sekali, maka pertumbuhan dan perkembangan gulma akan terhambat, bahkan dapat mengalami kematian (Goodall et al., 2010).

Berbagai cara pemberantasan gulma pada hutan tanaman sering dipraktekan. Umumnya gulma diberantas dengan herbisida, dibabad secara mekanis atau menebas secara manual (Samyu, 2009). Pemberantasan gulma secara mekanis memerlukan modal yang tinggi disertai persyaratan lahan datar (Teasdale, 2009). Pemberantasan secara kimia dapat membunuh gulma secara langsung hingga ke akar-akarnya, namun dapat menghasilkan residu yang tidak ramah lingkungan pada tanah (Youkhman, 2011). Oleh karena itu, perlu dicarikan cara lain untuk mengendalikan gulma. Salah satu cara yang perlu dilakukan adalah pengurangan gulma secara biologis dengan menggunakan mulsa organik berupa biomassa hidup atau mati yang ada di sekitar lokasi tanaman. Mulsa tersebut dapat berasal dari serasah berbagai jenis tumbuhan, bekas tebasan rumput atau jenis gulma itu sendiri yang dibusukan di atas pemukaan tanah. Tentunya mulsa dimaksud harus memiliki sifat lambat mengurai dan dapat menutupi penetrasi cahaya matahari agar proses perkecambahan benih gulma terhambat.

Pengendalian pertumbuhan gulma dengan menggunakan mulsa organik memiliki kelebihan, yaitu bahan mulsa mudah didapat di sekitar areal tanaman, dapat meningkatkan tambahan unsur hara, meningkatkan kehadiran organisme pengurai serasah dan ramah lingkungan (Cerrilo et al., 2009, Zawls, 2010). Pada prinsipnya penggunaan jenis mulsa diharapkan dapat menghambat pertumbuhan dan perkembangan gulma, tidak menghambat pertumbuhan tanaman pokok dan mengurangi resiko bahaya kebakaran (Samyu \& Bruno, 2009). Atas dasar permasalahan di atas, maka tujuan penelitian adalah untuk mengetahui pengaruh jenis dan ketebalan mulsa organik terhadap: (a) pertumbuhan dan perkembangan gulma serta (b) pertumbuhan tanaman dan kesuburan tanah di lingkungan hutan tanaman nyawai.

\section{METODOLOGI}

\section{A. Bahan, Waktu dan Lokasi}

Bahan-bahan yang digunakan adalah tegakan tanaman nyawai berumur 1 tahun dan jenis-jenis bahan mulsa organik yang terdiri dari daun alangalang, daun mahang, batang dan daun kirinyu, rumput Piper sp. dan rumput jepangan. Penelitian dilakukan di Kawasan Hutan Dengan Tujuan Khusus (KHDTK) Kintap Kalimantan Selatan. Secara geografis, lokasi penelitian berada antara $11,40^{\circ} 50^{\prime} 32^{\prime \prime}-11,50^{\circ} 19^{\prime} 53^{\prime \prime} \mathrm{BT}$ dan $30^{\circ} 36^{\prime} 53^{\prime \prime}-30^{\circ} 55^{\prime} 40^{\prime \prime} L S$. Jenis tanah termasuk podsolik merah kuning dan laterik dari bahan induk batuan beku dengan fisiografi dataran. Klasifikasi iklim menurut Schmidt \& Ferguson termasuk tipe iklim B dengan nilai $Q$ antara 13,3$33,33 \%$. Musim hujan terjadi pada bulan November hingga April dan musim kemarau terjadi pada bulan Mei hingga September. Ratarata curah hujan tahunan $3.017 \mathrm{~mm}$ per tahun dan rata-rata hari hujan 154 hari per tahun. Rata-rata temperatur udara $25^{\circ} \mathrm{C}$ (minimum $22,6^{\circ} \mathrm{C}$ dan maksimum $29,9^{\circ} \mathrm{C}$ ). Pelaksanaan penelitian dimulai pada bulan Januari 2012 sampai dengan Desember 2012.

\section{B. Metode}

Tahap pertama penelitian adalah memberantas gulma secara manual di dalam jalur tanaman nyawai dengan tujuan untuk menyamakan kondisi awal lahan. Nyawai ditanam dengan jarak tanam $3 \mathrm{~m} \mathrm{x} 4 \mathrm{~m}$. Jalur tanaman dibuat arah utara-selatan. Mulsa organik benih yang disemaikan melalui teknologi persemaian semi permanen. Mulsa organik ditimbang guna mengetahui bobot awal dan mulsa diletakkan atau ditumpuk seluas $50 \mathrm{~cm} \mathrm{x}$ $50 \mathrm{~cm}$ di atas permukaan tanah sekitar tanaman. Untuk menjaga keberadaan mulsa, setiap tanaman diberi dinding sarlon membentuk kubus. Pengukuran dilakukan setelah 3 bulan dari saat penutupan mulsa. Komponen gulma yang diamati meliputi jumlah jenis gulma dan kerapatan gulma yang dihitung dalam jumlah individu per luas $50 \mathrm{~cm}$ x $50 \mathrm{~cm}$. Kecepatan proses dekomposisi dengan mengukur penurunan bobot gulma. Pengukuran dilakukan 1 kali selama 3 bulan setelah pemasangan mulsa. Kesuburan tanah dianalisis di laboratorium tanah pada saat setelah perlakuan mulsa organik. Untuk mengetahui dampak pemberian mulsa terhadap tanaman, maka dilakukan pengukuran tinggi, diameter batang dan diameter tajuk tanaman pokok.

\section{Rancangan penelitian}

Rancangan penelitian menggunakan Rancangan Faktorial dalam Rancangan Acak 
Kelompok (5 x 2). Faktor pertama adalah jenis mulsa organik yang terdiri atas 5 taraf, yaitu mulsa daun Piper aduncum (M1 per Pr), mulsa Clibadium surinamense (M2 per Gm), mulsa daun Macaranga gigantica (M3 per Mg), mulsa rumput Imperata cylindrical (M4 per Ag), mulsa daun Cromolaena odorata (M5 per Ku) dan tanpa mulsa (kontrol). Faktor kedua adalah ketebalan tumpukan mulsa organik $(\mathrm{T})$ yang terdiri atas 2 taraf yaitu ketebalan $10 \mathrm{~cm}$ (T1) dan ketebalan 20 cm (T2). Setiap kombinasi perlakuan dikelompokan menjadi 4 kelompok dan setiap unit percobaan terdiri atas 4 pohon. Parameter gulma adalah jumlah jenis gulma yang tumbuh kembali, jumlah individu berbagai jenis gulma yang tumbuh dan kesuburan. Tingkat pertumbuhan tanaman nyawai yang diamati adalah tinggi, diameter batang dan diameter tajuk tanaman pokok.

\section{Analisis data}

Data dianalisis menggunakan uji $\mathrm{F}$ untuk mengetahui ada tidaknya pengaruh faktor tunggal dan interaksi yang terjadi. Selanjutnya dilakukan uji beda rata-rata dengan Uji Duncan. Parameter yang diamati yaitu indeks nilai penting, jenis gulma yang tumbuh kembali, jumlah individu gulma, penurunan biomassa mulsa, kandungan unsur hara $\mathrm{N}, \mathrm{P}$ dan $\mathrm{K}$ dari mulsa organik, pertumbuhan tinggi dan diameter tanaman nyawai, diameter tajuk tanaman nyawai dan kondisi kesuburan tanah setelah perlakuan mulsa.

\section{HASIL DAN PEMBAHASAN}

\section{A. Hasil}

Hasil analisis vegetasi jenis-jenis gulma yang tumbuh di sekitar tanaman nyawai menunjukkan ada 11 jenis gulma yang hidup di sekitar areal tanaman. Enam jenis gulma berada di dalam plot ialah alang-alang (Imperata cylindrica (L.) P.Beauv.), japangan (Clibadium surinamense L.), kirinyu (Chromolaena odorata (L.) King \& H.E. Robins.), cente (Lantana camara L.), teki (Cyperus rotundus L.) dan takokak (Solanum torvum Sw.). Lima jenis lagi tumbuh sangat jarang dan terpencar-pencar yaitu babadotan (Ageratum conizoides L.), paspalum (Pasvalum sp.), pakis (Nephrolevis bisserata (Sw.) Schott), karamunting (Melastoma malabatracum L) dan harendong bulu besar(Clidemia D.Don).

Jenis-jenis gulma kelompok dominan ditunjukkan oleh jenis rumput alang-alang dengan nilai dominansi 66,2 , diikuti oleh jenis jepangan dengan nilai dominansi 25,4. Empat jenis ditemukan ko dominan yaitu jenis kirinyu, cente, rumput teki dan takokak (Tabel 1).

\section{Pengaruh mulsa terhadap jumlah jenis gulma yang tumbuh kembali}

Hasil pengamatan selama 3 bulan setelah pemberian mulsa menunjukkan bahwa faktor ketebalan mulsa, kelompok dan interaksi jenis mulsa dengan ketebalan mulsa tidak berpengaruh nyata terhadap keanekaragaman jenis gulma yang tumbuh di sekitar tanaman nyawai, tetapi terhadap jenis mulsa berpengaruh signifikan (Gambar 1.)

Tabel (Table) 1. Keragaman gulma di bawah tegakan nyawai (Weed diversity under nyawai stand)

\begin{tabular}{|c|c|c|c|c|c|c|}
\hline $\begin{array}{c}\text { Jenis } \\
\text { (Species) }\end{array}$ & $\begin{array}{l}\text { Nama latin } \\
\text { (Latin name) }\end{array}$ & $\begin{array}{c}\text { Kerapatan } \\
\text { (Density) } \\
\text { (individu/ } \\
0,25 \mathrm{~m}^{2} \text { ) }\end{array}$ & $\begin{array}{c}\text { Frekuensi } \\
\text { (Frequency) }\end{array}$ & $\begin{array}{c}\text { Kerapatan } \\
\text { relatif } \\
\text { (Relative } \\
\text { density) } \\
(\%)\end{array}$ & $\begin{array}{c}\text { Frekuensi } \\
\text { relatif } \\
\text { (Relative } \\
\text { Frequency) } \\
(\%)\end{array}$ & $\begin{array}{l}\text { Indeks } \\
\text { nilai } \\
\text { penting } \\
\text { (Impotent } \\
\text { value index) }\end{array}$ \\
\hline Alang-alang & Imperata cylindrica & 40,0 & 1,0 & 46,19 & 20,0 & 66,2 \\
\hline Jepangan & Clibadium surinamense & 0,6 & 0,6 & 1,39 & 24,0 & 25,4 \\
\hline Kirinyu & Cromolaena odorata & 0,7 & 0,4 & 1,62 & 16,0 & 17,6 \\
\hline Cente & Lantana camara & 1,6 & 0,3 & 3,70 & 12,0 & 15,7 \\
\hline Teki & Cyperus rotundus & 0,2 & 0,1 & 0,46 & 4,0 & 4,5 \\
\hline Takokak & Solanum torvum & 0,2 & 0,1 & 0,46 & 4,0 & 4,5 \\
\hline
\end{tabular}




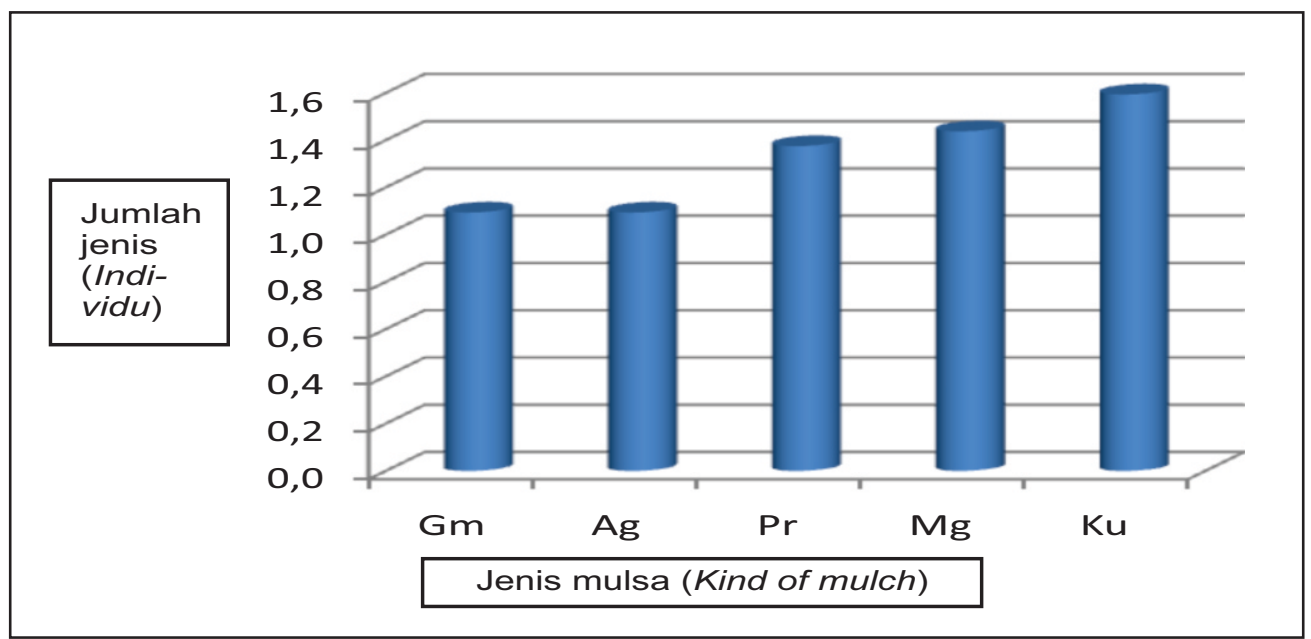

Keterangan (Remarks): $\mathrm{Gm}=$ mulsa C. surinamense $(\underline{\mathrm{C}}$. surinamense mulch), Ag = mulsa I. cylindrical $(\underline{\mathrm{I}}$. cylindrical mulch $)$, $\mathrm{Pr}=$ mulsa $P$. aduncum $(\underline{\mathrm{P} . \text { aduncum }}$ mulch $), \mathrm{Mg}=$ M. gigantic $(\underline{\mathrm{M}}$. gigantic mulch $), \mathrm{Ku}=C$. odorata $(\underline{\mathrm{C}}$. odorata mulch)

Gambar(Figure) 1. Jumlah gulma yang tumbuh 3 bulan setelah pemulsaan (Number of weeds 3 months after mulching)

Hasil uji Duncan menunjukkan bahwa antar mulsa dari bahan kirinyu, mahang dan $P$. aduncum menghasilkan jumlah jenis yang tidak berbeda nyata, namun berbeda signifikan dengan mulsa rumput jepangan dan mulsa alang-alang. Dengan demikian, mulsa rumput jepangan dan mulsa alang-alang efektif menekan pertumbuhan gulma sampai umur 3 bulan. Perlakuan kontrol menghasilkan 6 jenis gulma. Hasil uji beda ratarata antar jenis mulsa disajikan dalam Tabel 2.

\section{Pengaruh mulsa terhadap jumlah individu gulma sekitar tanaman}

Faktor jenis mulsa, ketebalan timbunan mulsa, kelompok dan interaksi belum mempengaruhi secara signifikan terhadap total jumlah individu gulma. Perlakuan kontrol (tanaman tanpa mulsa) telah menghasilkan semua jumlah gulma sebanyak 43 individu per $0,25 \mathrm{~m}^{2}$.

\section{Penurunan biomassa mulsa}

Faktor ketebalan timbunan gulma tidak berpengaruh nyata terhadap penurunan biomassa mulsa dan begitu juga tidak terjadi interaksi secara signifikan Pengelompokan dan jenis mulsa telah mempengaruhi penurunan biomasssa mulsa dalam waktu 3 bulan. Dalam waktu 3 bulan, jenis mulsa daun $P$. aduncum telah mengalami penurunan biomassa sebesar 90,3\% dari bobot awal. Penurunan persentase tersebut berbeda nyata dengan gulma jepangan dan kirinyu yang mengalami penurunan biomassa sebesar $81,7 \%$ dan $80,1 \%$. Penurunan bobot mulsa yang dialami oleh mulsa daun $P$. aduncum tidak berbeda nyata dengan mulsa daun mahang. Hasil analisis perbedaan kecepatan penurunan mulsa disajikan pada Tabel 3 .

Tabel(Table) 2. Pengaruh 5 jenis mulsa terhadap jumlah gulma yang tumbuh (Effectof 5 mulchs Duncanto number of weeds)

\begin{tabular}{clc}
\hline No. & \multicolumn{1}{c}{ Jenis mulsa (Kind of mulch) } & Jumlah gulma (Number of weed) \\
\hline 1. & C. surinamense & $1,1 \mathrm{a}$ \\
2. & I. cylindrical & $1,1 \mathrm{a}$ \\
3. & P. aduncum & $1,4 \mathrm{~b}$ \\
4. & M. gigantean & $1,4 \mathrm{~b}$ \\
5. & C. odorata & $1,6 \mathrm{~b}$ \\
\hline
\end{tabular}

Keterangan(Remarks): Nilai rata-rata diikuti huruf yang sama pada baris yang sama tidak berbeda nyata pada taraf $5 \%$ (The mean values followed by the same letter at the same row are not significantly different at 5\%) 
Tabel(Table) 3. Penurunan biomassa mulsa organik setelah 3 bulan pemulsaan (Biomass mulchs reduction after 3 months mulching)

\begin{tabular}{clc}
\hline No. & \multicolumn{1}{c}{ Jenis mulsa (Kinds of mulch) } & Biomassa (Biomass) $(\mathrm{g})$ \\
\hline 1. & I. cylindrica & $38,1 \mathrm{a}$ \\
2. & C. odorata & $80,1 \mathrm{~b}$ \\
3. & C. surinamense & $81,7 \mathrm{~b}$ \\
4. & M. gigantean & $89,2 \mathrm{c}$ \\
5. & P. aduncum & $90,3 \mathrm{c}$ \\
\hline
\end{tabular}

Keterangan(Remarks): Nilai rata-rata diikuti huruf yang sama pada baris yang sama tidak berbeda nyata pada taraf $5 \%($ The mean values followed by the same letter at the same row are not significantly different at 5\%)

Penurunan biomassa paling lambat dialami oleh mulsa alang-alang. Kecepatan penurunan biomassa kirinyu tidak berbeda nyata dengan jepangan. Alang-alang memiliki kecepatan pengurangan biomassa terendah. Hasil analisis laboratorium menunjukkan bahwa kandungan unsur hara $\mathrm{N}, \mathrm{P}$ dan $\mathrm{K}$ dari mulsa cukup bervariasi. Mulsa daun Macaranga gigantea memiliki kandungan nitrogen (N) tertinggi diantara mulsa lainnya. Mulsa daun Piper aduncum mengandung phospor (P) tertinggi diantara jenis mulsa lainnya. Mulsa daun Cromolaena odorata memiliki kandungan kalium $(\mathrm{K})$ tertinggi daripada yang lainnya. Data kandungan unsur $\mathrm{N}, \mathrm{P}$ dan $\mathrm{K}$ dari 4 jenis mulsa tersaji di dalam Gambar 2.

\section{Pengaruh mulsa terhadap pertumbuhan tinggi tanaman}

Pemberian mulsa organik pada tanaman nyawai tidak berpengaruh nyata terhadap pertumbuhan tinggi tanaman nyawai, kecuali tebal mulsa yang berpengaruh nyata terhadap pertumbuhan tinggi tanaman sedangkan jenis mulsa dan interaksinya dengan ketebalan mulsa tidak berpengaruh nyata terhadap pertumbuhan tinggi. Ketebalam mulsa terbaik adalah $20 \mathrm{~cm}$. Pengaruh yang sangat nyata dari pengelompokan pada setiap perlakuan menunjukkan bahwa penggunaan Rancangan Acak Kelompok sudah sangat tepat, karena jika tempat tumbuh tidak dikelompokan maka pengaruh perlakuan akan bias. Penambahan tinggi yang terjadi 3 bulan setelah pemberian mulsa piper. sebesar $26,1 \mathrm{~cm}$, mulsa daun mahang sebesar $26,5 \mathrm{~cm}$, mulsa alang-alang sebesar $29,7 \mathrm{~cm}$, mulsa kirinyu sebesar 31,4 cm dan mulsa jepangan sebesar 31,4 $\mathrm{cm}$. Tetapi variasi tersebut tidak berbeda nyata secara statistik.

\section{Pengaruh mulsa terhadap pertumbuhan diameter}

Hasil pengujian pengaruh kombinasi mulsa organik dengan ketebalannya terhadap pertum-

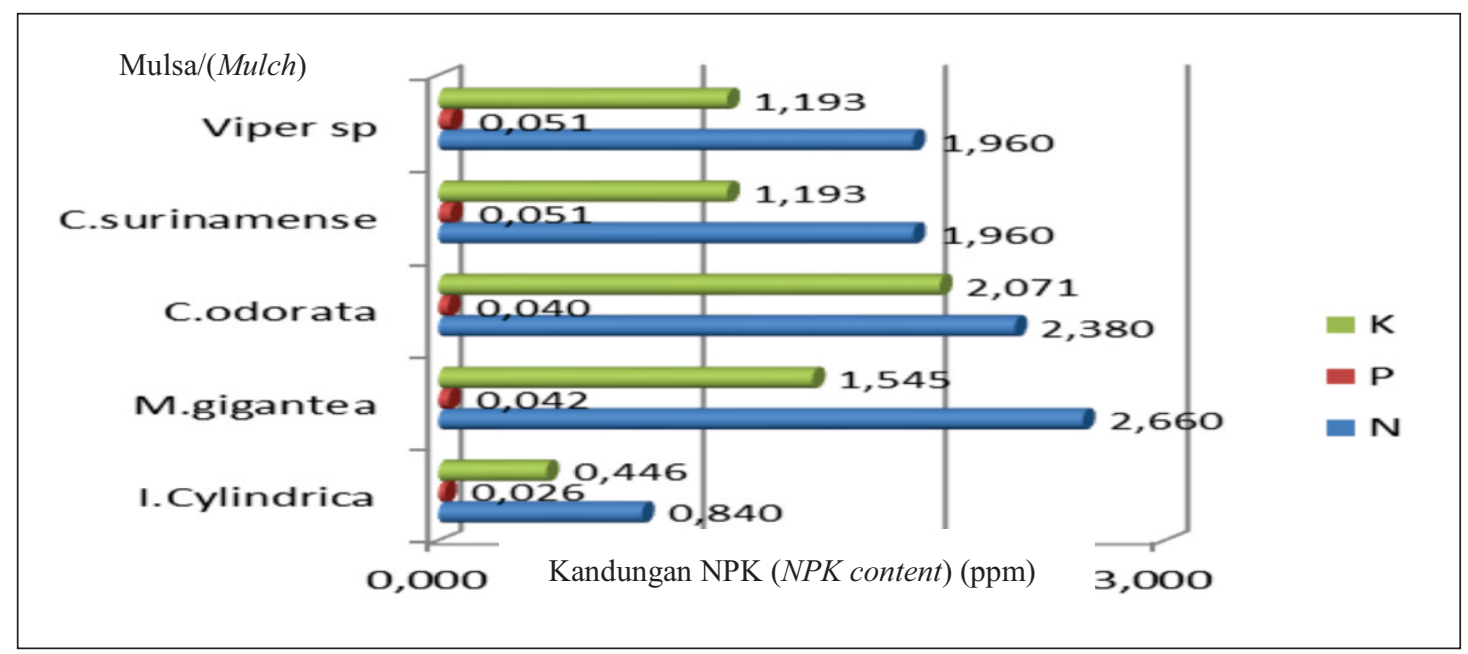

Gambar (Figure) 2. Kandungan unsur hara N, P dan K yang ada di 5 mulsa organik ( $N$, $P$ and $K$ contens of 5 organic mulchs) 
buhan diameter batang nyawai menunjukkan tidak adanya pengaruh nyata. Dalam percobaan ini pengelompokan dari perlakuan-perlakuan yang diberikan menunjukkan perbedaan yang sangat nyata, hal tersebut berarti bahwa penggunaan desain rancangan acak kelompok sangat tepat dalam percobaan ini. Jika tidak, maka hasil pengaruh perlakuan akan terdominasi oleh pengaruh kelompok menjadi bias. Dalam waktu 3 bulan, pemberian mulsa organik baik jenis mulsa, ketebalan mulsa dan interaksinya belum menunjukkan pengaruh yang signifikan terhadap pertumbuhan diameter nyawai.

\section{Pengaruh mulsa terhadap pertumbuhan diamater tajuk}

Sama halnya dengan pengaruh interaksi antara jenis mulsa dengan ketebalan lapisan mulsa terhadap tinggi, ternyata kombinasi perlakuan tersebut juga tidak berpengaruh nyata terhadap pertumbuhan diameter tajuk. Pengaruh kelompok sangat nyata menunjukkan adanya perbedaan kondisi tempat tumbuh di areal percobaan yang sangat nyata. Hasil analisis tanah pasca perlakuan mulsa organik disajikan dalam Gambar 3. Mulsa Piper sp., menghasilkan unsur hara pospor dan kalium tertinggi serta mulsa $\mathrm{C}$. surinamense memberikan $\mathrm{pH}$ dan nitrogen tertinggi.

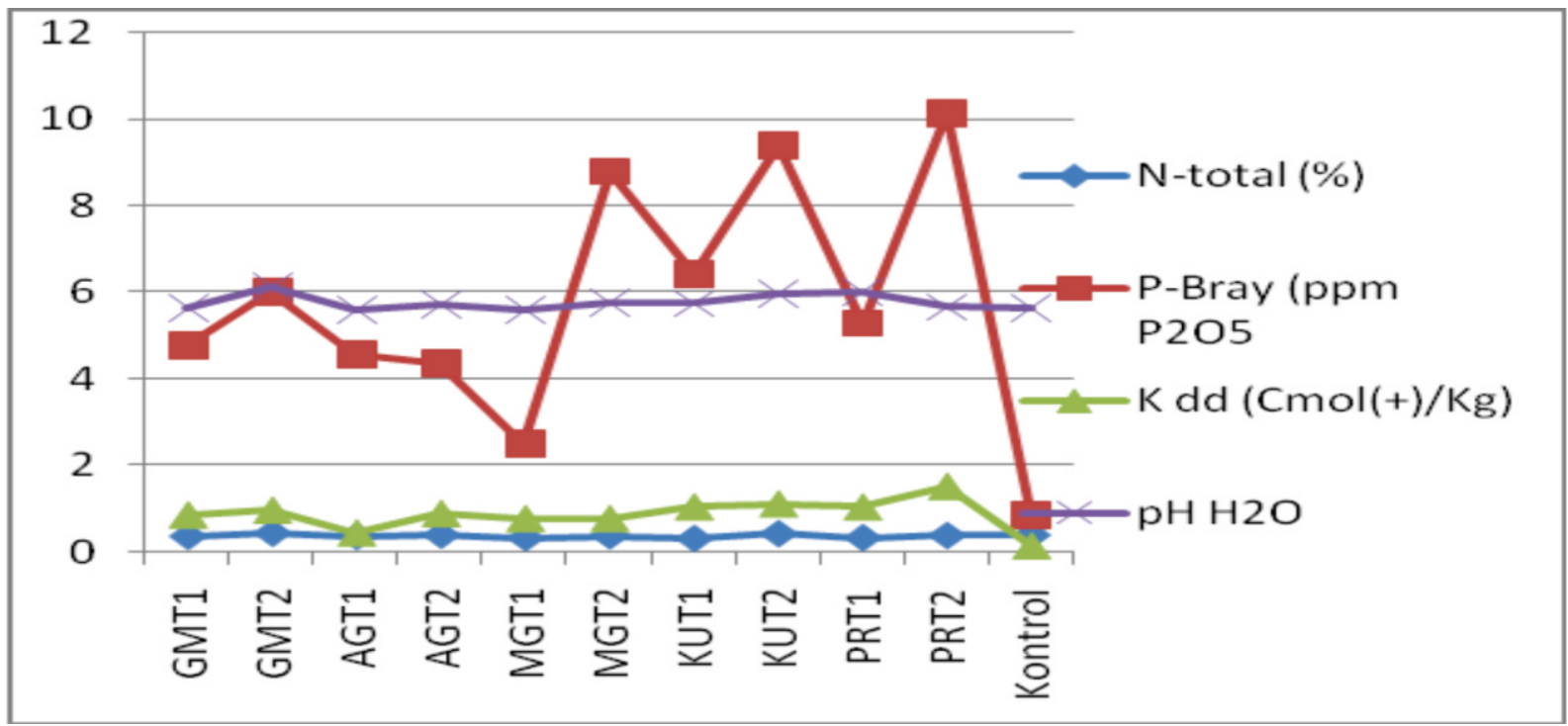

Keterangan (Remarks): GMT1 = mulsa C. surinamense tebal $10 \mathrm{~cm}($ C. surinamense mulch $10 \mathrm{~cm}$ thick), GMT2 $=$ mulsa $C$. surinamense $20 \mathrm{~cm}$ (C. surinamense mulch $20 \mathrm{~cm}$ thick), AGT1 = mulsa I. cylindrical tebal $10 \mathrm{~cm}(I$. ylindrical mulch $10 \mathrm{~cm}$ thick), AGT2 = mulsa I. ylindrical tebal $20 \mathrm{~cm}$ (I. cylindrical mulch $20 \mathrm{~cm}$ thick), PRT1 = mulsa $P$. aduncum tebal $10 \mathrm{~cm}(P$. aduncum mulch $10 \mathrm{~cm}$ thick), PRT2 = mulsa $P$. aduncum tebal $20 \mathrm{~cm}$ (P. aduncum mulch $20 \mathrm{~cm}$ thick), MGT1 = M. gigantic tebal $10 \mathrm{~cm}$ (M. gigantic mulch $10 \mathrm{~cm}$ thick), MGT2 = M. gigantic tebal $20 \mathrm{~cm}$ (M. gigantic mulch $20 \mathrm{~cm}$ thick), KUT1 =C. odorata tebal $10 \mathrm{~cm}$ (C. odorata mulch $10 \mathrm{~cm}$ thick), KUT2 = C. odorata tebal $20 \mathrm{~cm}$ (C. odorata mulch $20 \mathrm{~cm}$ thick)

Gambar(Figure)3. Kandungan hara tanah setelah penutupan dengan isa organik (Nutrient soil content after organic mulching) 


\section{B. Pembahasan}

Hasil penelitian menunjukkan potensi alangalang untuk dijadikan mulsa pada tanaman nyawai cukup besar karena selain tumbuh dominan, jenis rumput tersebut memiliki masa mengurai yang lebih lama. Hal tersebut didukung juga oleh jumlah gulma yang tumbuh paling sedikit menembus mulsa sekitar tanaman nyawai. Mulsa yang lambat mengurai akan lebih lama melembabkan tanah dan menstabilkan suhu, sehingga mendorong mikroba-mikroba tanah membantu proses dekomposisi di atas permukaan tanah (Suharatun, 2006). Di sisi lain sebagai perbandingan bahwa mulsa organik bekas pemanenan hutan tanaman telah memperbaiki struktur dan aerasi tanah dan meningkatkan bahan organik tanah (Bakr et al., 2012). Akibat tumbuh dominan di sekitar tanaman nyawai, maka ketersediaan alang-alang sebagai bahan mulsa cukup tinggi dan mudah diperoleh. Namun alang-alang sebagai gulma, jenis ini sering meningkatkan kerawanan kebakaran di musim kemarau (Cerrillo, 2009; Li, 2012). Jika alang-alang dimanfaatkan menjadi mulsa pada hutan tanaman, maka bahaya kebakaran bisa ditekan dan justu akan menghambat penguapan (evaporasi) serta menghambat tumbuh berbagai jenis guma.

Perbedaan karakter mulsa dalam menghambat pertumbuhan gulma diantaranya dipengaruhi oleh kondisi overlaping antar bagian mulsa yang berbeda-beda pada saat menutupi tanah. Sifat lain adalah kandungan kimia tumbuhan bahan mulsa (Elly et al., 2009; Rhoades et al., 2012). Kandungan kimia tanaman menentukan cepat lambatnya mulsa organik mengurai di atas permukaan tanah. Mulsa organik yang banyak mengandung lignin dan selulosa akan lebih lambat terdekomposisi daripada mulsa organik yang banyak mengandung karbohidrat, lemak dan protein (Samyu, 2009). Selain adanya perbedaan-perbedaan sifat tumbuh, terdapat kesamaan sifat yaitu hampir semua gulma tidak akan tumbuh normal apabila kekurangan cahaya matahari (Elly, 2009). Pada saat benih berkecambah sering mengalami kematian atau ketidak-normalan hidup akibat ketidaklancaran melakukan fotosintesis karena cahaya matahari kurang atau tidak ada sama sekali. Di sisi lain, mulsa organik akan memberikan sumbangan bahan organik dan unsur hara secara perlahan pada tanah di sekitarnya (Rhoades et al., 2012).
Pengaruh interaksi yang tidak nyata antara jenis gulma dengan ketebalannya terhadap perkembangan gulma dintaranya diakibatkan oleh ketidakseragaman ukuran serpihan-serpihan daun, sehingga sulit untuk membedakan porositas antar 2 ketebalan jika dihubungkan dengan perbedaan kemudahan hancurnya serpihan daun pada mulsa. Dengan demikian, penetrasi cahaya yang masuk dan evaporasi yang terjadi akibat ketebalan lapisan antar jenis gulma tidak dapat dibedakan, kecuali akibat jenis mulsa secara tersendiri.

Hal yang penting manfaat penggunaan mulsa alang-alang bahwa jumlah jenis gulma yang tumbuh menjadi sedikit. Hal ini diakibatkan oleh serpihan-serpihan alang-alang lama mengalami kehancuran. Serpihan-serpihan daun yang tidak hancur telah mengurangi cahaya masuk dalam waktu yang lama dan uap air banyak dikembalikan lagi ke tanah. Dengan demikian, tanah lebih lama mengalami kondisi lembab. Kondisi demikian biasanya proses perkecambahan dan rejuvenasi berbagai jenis gulma terhambat (Goodall et al., 2010). Terhambatnya pertumbuhan suatu jenis gulma akan lebih mendukung perkembangan gulma-gulma yang tumbuh toleran terhadap naungan.

Bahan-bahan mulsa yang mengalami penurunan biomassa lebih cepat akibat proses penguraian dan perombakan bahan-bahan lebih cepat. Perombakan yang cepat akibat hadirnya sejumlah mikroorganisme dekomposer atau bahan organik tersebut mengalami proses biodeteriorasi (Bakr et al., 2012; Prats et al., 2012) Kejadian inilah yang dialami oleh mulsa daun Piper sp. dan daun mahang yang paling cepat membusuk dan berbeda dengan daun kirinyu dan rumput jepangan sedangkan alangalang menunjukkan proses dekomposisi paling lambat.

Pertumbuhan tinggi, diameter batang dan diameter tajuk nyawai tidak dipengaruhi oleh keberadaan mulsa organik. Pemberian mulsa organik dalam waktu 3 bulan belum cukup meningkatkan pertumbuhan tanaman nyawai. Unsur hara yang dibutuhkan tanaman nyawai diduga masih cukup tersedia dari unsur-unsur anorganik yang ada pada lantai hutan. Hubungan keberadaan mulsa organik dengan pertumbuhan tanaman dapat bersifat langsung dan tidak langsung. Hubungan langsung terjadi dimana jenis mulsa yang mudah mengurai akan segera memberikan unsur hara tambahan pada tanaman. Bagi jenis mulsa yang lambat mengurai, 
sumbangan terhadap pertumbuhan bersifat tidak langsung yaitu dapat menigkatkan aktivitas mikroorganisme pengurai bahan-bahan organik yang ada pada permukaan tanah menjadi unsur hara tersedia bagi tanaman. Dalam penelitian ini waktu 3 bulan menunjukkan belum terjadinya proses penambahan unsur hara untuk tanaman nyawai baik bagi yang cepat mengalami penurunan biomassa maupun yang lambat. Bagi yang cepat, diduga proses penguraian unsur hara yang terjadi baru pada tahap amonifikasi, belum pada tahap nitripikasi (Rhoades, 2012). Hasil analisis tanah belum memenunjukkan adanya variasi kesuburan pasca pemulsaan.

Semua hasil analisis data dapat dijelaskan bahwa penggunaan mulsa organik telah terbukti dapat mengendalikan gulma. Hasil-hasil studi yang ada dapat mengarahkan kepada kesimpulan bahwa penggunaan mulsa organik yang lambat terurai akan lebih menguntungkan tanaman karena mulsa tersebut dapat menekan gulma yang tumbuh sebagai kompetitor tanaman nyawai serta senantiasa memberi kelembaban tanah yang lebih lama terutama saat musim kering ketika tanaman masih muda.

\section{KESIMPULAN DAN SARAN}

\section{A. Kesimpulan}

Kehadiran jenis gulma dipengaruhi secara nyata oleh faktor tunggal jenis mulsa. Pemberian mulsa selama 3 bulan belum mempengaruhi pertumbuhan tanaman nyawai umur 12 bulan. Kecepatan pengurangan biomassa mulsa berbeda nyata antar jenis mulsa. Mulsa daun M. gigantea dan Piper sp. mengalami pengurangan biomassa tercepat dari 5 jenis mulsa yang diujikan, sedangkan mulsa alang-alang (I. cylindrica) memiliki pengurangan biomassa paling lambat. Oleh karena itu, mulsa alang-alang mampu menekan gulma dengan efektif selama 3 bulan. Selain itu, mulsa alang-alang lambat dalam proses dekomposisi, sehingga diharapkan mampu menekan bahaya kebakaran. Sumbangan bahan organik dari mulsa terhadap kesuburan tanah menunjukkan bahwa mulsa Piper sp. menghasilkan unsur hara $\mathrm{P}$ dan $\mathrm{K}$ tertinggi dan mulsa C. surinamense memberikan unsur hara $\mathrm{N}$ tertinggi. Mulsa daun M. gigantea memiliki kandungan hara $\mathrm{N}$ tertinggi $(2,66 \%)$ dibanding mulsa lainnya. Mulsa daun Piper sp. mengandung hara $P$ tertinggi $(0,051 \%)$ dibanding mulsa lainnya, dan mulsa $C$. odorata memiliki kandungan hara $\mathrm{K}$ tertinggi (2,07\%) dibanding jenis mulsa lainnya.

\section{B. Saran}

Dalam upaya pemanfaatan mulsa organik ramah lingkungan dari gulma yang ada sekitar tanaman nyawai, maka disarankan menggunakan mulsa daun alang-alang.

\section{UCAPAN TERIMA KASIH}

Penelitian ini didanai oleh DIPA Badan Penelitian dan Pengembangan dan Inovasi, Balai Litbang Lingkungan Hidup dan Kehutanan Banjarbaru. Ucapan terima kasih disampaikan kepada Teknisi Eko Priyanto, S.Hut dan Sukma Alamsyah yang telah membantu kegiatan penelitian baik secara administrasi maupun pengamatan di lapangan.

\section{DAFTAR PUSTAKA}

Bakr, N., Weindorf, D.C., Yuanda, Z., Allen, E.A., \& Selim, H.M. (2012). Evaluation of compost/ mulch as highway embankment erosion control in lauisiana at the plat-scall. Elsevier. Journal of hydrology, Voluem (Nomor), 41-47.

Cerrillo, R.M.N., Ariza, D., Gonzales, L, Compo, A.D., Arjono, M., \& Ceacera, C. (2009). Legume living mulch for afforestation in agricultural land in Southern Spain. Elsevier. Soil Tillage Research,1026 (2009), 38-44.

Effendi, R. (2010). Pengelolaan hutan tanaman penghasil kayu pertukangan. rencana penelitian integratif. Pusat Penelitian dan Pengembangan Peningkatan Produktivitas Hutan. Bogor.

Elly I.S., (2009). Pengaruh takaran mulsa jerami dari beberapa varietas padi terhadap penekanan gulma pada tanaman kedelai. Skripsi Fakultas Pertanian Unibraw. Malang.

Goodall, J., Witkowski, T.F, Amman, S., \& Reinhardt, C. (2010). Does allelopathy explain the invasiveness of compuloclinium macrocephallum (pompom weed) in South Aprica Grassland Biome?. Biol Invasions, $12.3497512,22-28$

Nagochi, H.K., Fushimi ,Y., \& Shigemori, H. (2009). Plant Physiology, 566, 442-446.

Li, S.X., Wang, Z.H., Li, S.Q., Geo, Y.J., \& Tan, X.H. (2012). Effect of plastic sheet mulch, wheat straw mulch, and maize growth on water loss 
by evaporation in clayland areas of China. Elsevier. Agricultural water management, 4447.

Prats, S.A., Donald, L.H.M., Monteiro, M., \& Antonio, J.D.F. (2012). Effectiveness of forest residue mulching in reducing post-fire run off end erosion in a fine and a Eucalypt plantation in north-Central Portugal. Elsevier. Journal homepage: www.elsevier.com/locate/ geoderma, 22-25.

Samyu, J., \& Bruno, D.V. (2009). The assessmen of mulch sheets to inhibit competitive vegetation in tree plantation in urban and natural environment. Urban Forestry, 44-46.

Suharatun, S. (2006). Peranan beberapa jenis mulsa organik dalam manajemen suhu. Lembaga Penelitian Universitas Lampung. Bandarlampung. 25 hal.

Teasdale, J.R., \& Cavigelli, M.A. (2009). Subplots facilitate assessment of corn yield losses from weed competition in a long-term systems experiment. Journal homepage. www.elsevier.com/locate/foreco, 35-38.
Rhoades, C.C., Battoglia, M.A. Rocca, M.E., \& Rian, M.G. (2012). Short and Medium term effects of fuel reduction mulch treatment om soil nitrogen availability in Colorado conifer forest, Elsevier. Forest Ecology and Management. Journal homepage: www.elsevier.com/locate/foreco, 04, 42-27.

Samyu, J., \& De Vos, B. (2009). The assessment of mulch sheets to inhibit competitive vegetation in tree plantations in urban and natural environment. Urban Forestry and Urban Greening. http://www.urbanfischer.da/ journals/ufug, 11-15.

Youkhman, A., \& Travis, I. (2011). Addition of Leucaena-KX2 mulch in a shaded caffel agroforestry system increas both stable and labile soil C. Fraction. Elsevier. Soil Biology and Biochemistry Journal. homepage: www.Elsevier.con/locate/soilbio, 10, 32-29.

Zawls, T.Z. (2010). Reestablishment of ecological functioning by mulching and termite invasion in a degraded soil in an Australian Savana. Elsevier. Soil Biologys as Biochemistry. Northern Territori, 0822, 45-48. 